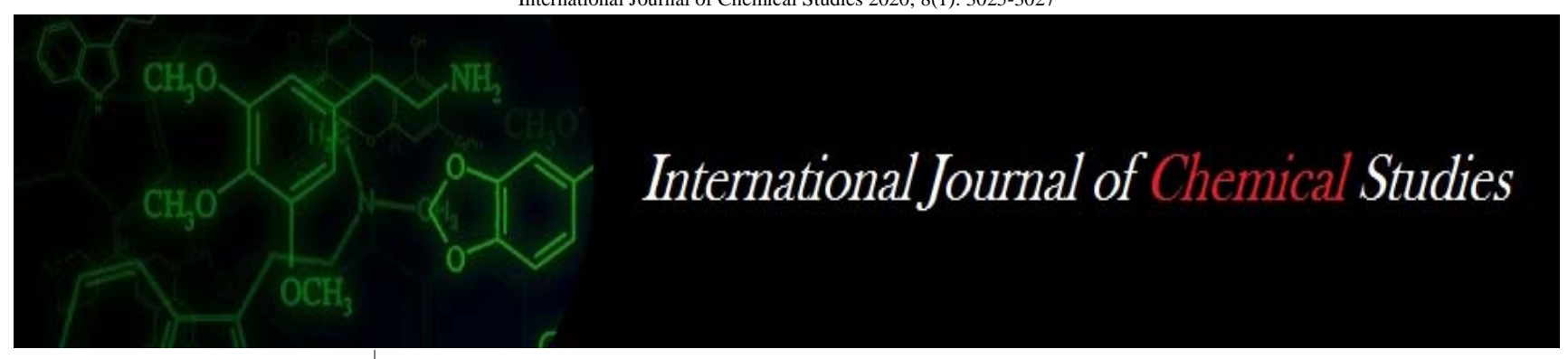

P-ISSN: 2349-8528 E-ISSN: 2321-4902 www.chemijournal.com IJCS 2020; 8(1): 3025-3027 (C) 2020 IJCS

Received: 21-11-2019

Accepted: 25-12-2019

Baby Kumari

Department of Plant Pathology, Bihar Agricultural University

Sabour, Bhagalpur, Bihar, India

Sanjay Kumar Suman

Home Science-Food \& Nutrition

Department, S.M. College, T.M.

Bhagalpur University,

Bhagalpur, Bihar, India
Corresponding Author: Baby Kumari

Department of Plant Pathology, Bihar Agricultural University Sabour, Bhagalpur, Bihar, India

\section{Impact of different spawn substrates on production of Button mushroom [Agaricus bisporus (Lange), Sing]}

\author{
Baby Kumari and Sanjay Kumar Suman
}

DOI: https://doi.org/10.22271/chemi.2020.v8.i1at.8732

\section{Abstract}

An experiment was conducted to determine the best substrate for Agaricus bisporus spawn production and cultivated on the compost in Bihar, India. The cereal grains of Wheat (Triticum aestivum), Maize (Zea mays) and Paddy (Oriza sativa) were evaluated as spawn substrate. Agaricus bisporus was incubated at $24 \pm 1^{\circ} \mathrm{C}$ for spawn development. Observations were recorded for number of days taken for spawn development. Spawn raised on different grains was also used for cultivation on compost to assess the period of spawn run, number of days taken for pinhead initiations and weight of fruiting body. The shortest period for spawn development (11.6 days) was obtained with wheat grains indicating its suitability for efficient spawn production. The different grains also influenced the duration of spawn run, pin-head formation. Highest yield of Agaricus bisporus was recorded on wheat grain spawn and it was followed by maize spawn.

Keywords: Agaricus bisporus, compost, spawn, growth, yield

\section{Introduction}

Mushrooms have been favored as food by mankind since time immemorial being collected from the forests. There are 14,000 known species of mushrooms of which 2,000 are safe for human consumption and about 650 of these possess medicinal properties. Among the total known mushrooms, approximately 850 species are recorded from India. (Thatoi and Singdevsachan, 2014) ${ }^{[5]}$. About 20 mushroom species are now produced commercially worldwide (Sánchez, 2004). Mushroom mycelia secrete enzymes that break down lignocelluloses which are then absorbed by the hyphae and the mycelium enlarges usually laterally and in some cases growing several meters in diameter with the substrate. Mushrooms are very nutritious products. It can serve as food, as tonic, and as medicine. A regular intake of mushrooms can make you healthier, fitter, happier, live longer and always look younger. They are rich in crude fibre and protein. They contain low fat, low calories and good vitamins. Mushroom farming is a business which requires precision. Indeed, it is not as simple as what some people often loosely stipulate. Mushroom cultivation technology is friendly to the environment and a labour intensive activity. Therefore, it will serve as means of generating employment, particularly for rural women and youths in order to raise their social status. It will also provide additional work for the farmers during winter months when the farming schedule is light. Spawn is the propagating material used for mushroom production. Quality of spawn is the base of successful mushroom cultivation. Due to these promising characters, the current study mainly focused on finding the suitability of different grains as spawn substrates and their effect on yield of Agaricus bisporus.

\section{Materials and Methods}

The spawn of Agaricus bisporus was prepared on different grains such as Wheat (Triticum aestivum), Maize (Zea mays) and Paddy (Oriza sativa). The cereal grains used were obtained from the Agro-farm, B.A.U. Sabour Bhagalpur. The grains were separately washed and steeped overnight in water. They were then thoroughly washed separately with tap water to ensure that dust and other particles had been removed, drained, tied in a wire mesh and boiled with equal amount of water till grains become soft but were not allowed to split open. The 
moisture content of boiled grains was allowed to leave as such for hours for air drying so that water on surface is evaporated to obtain 50 to 55 per cent moisture. Then the grains are mixed with 0.5 per cent calcium carbonate and 2.0 per cent calcium sulphate so that the $\mathrm{pH}$ of the grains is around 7.0 to 7.8 and they do not form clumps. First gypsum and chalk powder are mixed separately and then they are thoroughly mixed with grains. This substrate was filled into $15 \times 20 \mathrm{~cm}$ size polypropylene bags. The mouth part of container was plugged with clean, non-absorbent cotton and cotton cap covered with Aluminum foil. These polypropylene bags were sterilized for two hour at 22 pound pressure $\left(126^{\circ} \mathrm{C}\right)$.

\section{Inoculation and incubation of grains}

After cooling the sterilized polypropylene bags for 24 hours, the content was inoculated with one-week-old pure tissue cultures of Agaricus bisporus. Each of the polypropylene bag sterilized grains was aseptically inoculated with one $1 \mathrm{~cm}^{2}$ of the one-week-old tissue culture of the experimental strain grown on Potato Dextrose Agar using a flamed and cooled scalpel in a laminar flow hood. Thereafter the containers were incubated to attain complete ramification over the substrate at 22-25 ${ }^{\circ} \mathrm{C}$. These seed materials were used freshly for cultivation of aforementioned mushroom.

\section{Box preparation and mushroom cultivation}

The spawn was mixed with compost @ 500 gm/100 kg of compost and filled in formalin sterilized wooden boxes $(60 \mathrm{x}$ $90 \times 15-23 \mathrm{cms}$, accommodating $6 \mathrm{~kg}$ compost) and covered with formalin sterilized newspaper sheet to prevent loss of moisture content in mushroom beds. These mushroom boxes were placed in growing chamber, where temperature range between 22-28 ${ }^{\circ} \mathrm{C}$ and 90-95\% RH (Relative Humidity). The paper over the beds was sprayed regularly with water to prevent drying out and humidity was built up by frequently watering the floor and walls. The room was kept closed as only a small amount of fresh air recirculating within the crop room for maintain the carbon dioxide levels . Mushroom boxes were completely colonized by mushroom mycelium within (20-31days). The compost becomes lighter in colour and the mycelium seen as thin white-threads.

\section{Presentation of data}

The data recorded in respect of yield parameters were time lapsed in spawn run, and pin head initiation, number of pin head, number of fruiting body and total yield on different kinds of spawn.

\section{Statistical Method}

All experimental data were statistically analyzed by using Factorial Completely Randomized Block Design. The significance of each data was analyzed by calculating critical difference at1 per cent level.

Table 1: Effect of different grain spawns on yield performance of button mushroom

\begin{tabular}{|c|c|c|c|c|c|c|}
\hline $\begin{array}{c}\text { Spawn substrate } \\
\text { (Grains) }\end{array}$ & $\begin{array}{c}\text { Incubation Period } \\
\text { for Spawn } \\
\text { development } \\
\text { (Days) }\end{array}$ & $\begin{array}{c}\text { Spawn run } \\
\text { (Days) }\end{array}$ & $\begin{array}{c}\text { Pinhead } \\
\text { initiations } \\
\text { (Days) }\end{array}$ & $\begin{array}{c}\text { Average } \\
\text { number of } \\
\text { pinhead } \\
\text { initiations }\end{array}$ & $\begin{array}{c}\text { Average } \\
\text { number of } \\
\text { fruiting body }\end{array}$ & $\begin{array}{c}\text { Total yield from } \\
\text { four flushes } \\
\text { [gm/box] }\end{array}$ \\
\hline C1 - Wheat & 11.6 & 21.33 & 16.83 & 233.333 & 69.67 & 941.93 \\
\hline C2 - Paddy & 16.6 & 25.88 & 18.57 & 134.666 & 55.67 & 610.20 \\
\hline C3 - Maize & 14 & 26.66 & 22.02 & 196.333 & 62.00 & 671.60 \\
\hline CD (P-0.01) & 1.509 & 0.738 & 0.248 & & & \\
\hline SEm ( \pm ) & 0.489 & 0.248 & 0.125 & & & \\
\hline
\end{tabular}

\section{Results and Discussion}

The results regarding various parameter of mushroom production are presented in Tables 1 .

\section{Effect of grain spawn on cultivation of Agaricus bisporus} The spawn was developed on different kinds of cereals outlined by (Aneja, 2004) ${ }^{[1]}$. The grain substrates were inoculated with mother spawn of mushroom and incubated for mycelial run. The incubation period varied among themselves which ranged 11.6-16.6 days (Table.1). For the spawn development, wheat grains registered least incubation time (11.6 days). Once spawn was prepared, it was planted in to the substrate where they showed variable effect on duration of spawn run and pinhead initiation which ranged from 21.3326.66 days and 21.33- 26.66 days respectively. The longer period (26.67 days) was taken by maize spawn while lower period (21.33 days) taken by wheat spawn. Number of pinhead and fruiting bodies at different flushes was also followed a similar trend with highest 233.33 and 69.67 respectively in wheat spawn and lower 134.66 pinhead and 55.67 fruiting body in paddy spawn. Table- 1 revealed that, out of all grains spawn under taken in this study, wheat spawn was found superior over paddy spawn and maize spawn. Wheat spawn gave maximum yield (941.93g/box), whereas paddy spawn gave minimum yield (610.20g/box) and followed by maize spawn (671.60g/box).

The results of the present investigation are in close agreement with the results reported by Rafique (1998) ${ }^{[2]}$ in Pleurotus spp. he reported thuli (crushed wheat grains) spawn was best, producing the most rapid mycelial growth and highest yield in all Pleurotus spp. The cropping period (from the spawn run to the last harvest) was reduced by up to 4 days when thuli spawn was used. Verma et al., (2008) ${ }^{[6]}$ also reported the maximum yield was recorded from wheat grains spawn. Within the evaluated different grains spawn like wheat, mandua and jhangora for production of $P$. sajor-caju under prevailing environmental conditions during 2004-05. Mishra et al., (2012) ${ }^{[3]}$ reported that, wheat grains were found most suitable substrate as it took minimum time period (17 days) for spawn development of Flammulina velutipes .

\section{Conclusion}

In the present study three kinds of cereals grain (wheat, paddy and maize) were tested for spawn production of Agaricus bisporus, and wheat grain was selected best for spawn production. Wheat grains provide good food base for the fungal species to grow throughout the substrate, also described that wheat is easily available and cheaper than other substrates. 


\section{References}

1. Aneja KR. Mushroom production technology. In: Experiments in Microbiology Plant Pathology and Biotechnology (Fourth Edition). New Age International Limited, Publishers. New Delhi, 2004, 496-519.

2. Rafique A. Preparation and evaluation of spawn for the cultivation of Pleurotus in Gujarat. J of Scientific \& Indus. Res. 1998; 57:143-147.

3. Mishra KK, Mishra P, Kushwaha KPS. Cultural, Morphological and Yield Atributes of Winter Mushroom Flammulina velutipes (Curt. Fr.) Sing. J Mycol Plant pathol. 2012; 42:167-171.

4. Sánchez C. Modern aspects of mushroom culture technology. Applied Micro. Bio techno. 2004; 64:756762.

5. Thatoi H, Singdevsachan SK. Diversity, nutritional composition and medicinal potential of Indian mushrooms: A review Afr. J Bio technol. 13: 523-545.

6. Verma RC, Mishra KK, Singh RP. Evaluation of locally available substrates and grains spawn for production of Pleurotus sajor-caju. Int. J of Agric. Scie. 2008; 4:450452. 